\title{
Ssciendo
}

Ethics \& Bioethics (in Central Europe), 2020, 10 (3-4), 133-145

DOI:10.2478/ebce-2020-0014

\section{Ethics of responsibility in Ján Palárik’s civic liberalism}

\author{
Marcel Martinkovič ${ }^{1}$
}

\begin{abstract}
The development of the individual attributes of ethics of responsibility in conjunction with the principles of civic liberalism in Slovak political thought is associated with the thinking of Ján Palárik. His political ideas published in the second half of the $19^{\text {th }}$ century come out of an effort to characterize and achieve reform of the Habsburg monarchy on the basis of constitutionalism and federalism. These attributes, in Palárik's opinion, were to bring more effective solutions to the issue of educating people in their mother tongue and the creation of civic culture. A part of Palárik's approach to the formation of civic skills is also the advocating of free expression, the idea of pluralism and gradualism within the idea of the unity of the different. His realistic approach to politics was framed by knowing and respecting the objective limits when implementing the aims of national civic freedom. Palárik linked the development of the state and the process of acculturation of the people with application of the principles of practical reasonableness and ethics of responsibility. He found its essence in understanding the interconnectedness of political goals and ideals, which were to be reflected in close association with the real limitations of the capabilities of individuals and social circumstances.
\end{abstract}

Keywords: Ján Palárik, ethics of responsibility, civic culture, principle of pluralism, practical reasonableness

\section{Introduction}

The aim of the present study is to describe the ideological contribution of Ján Palárik's political thinking in Slovak philosophical-political discourse. The study builds on research into the development of Slovak political, cultural and ethical thinking (Gašparík, 1952; Várossová, 1963; Vavrovič, 1974; Katuninec, 2007; Maxwell, 2009, Pichler, 2011; Teich, Kováč \& Brown, 2011; Gluchman, 2012). In the study, the focus is on selected aspects of Palárik's thinking, which he connected with the implementation of individual and collective rights in transforming society (Haydanka, 2014). These two dimensions of modern rights were interpreted as competing with one another in the discourse of the second half of the $19^{\text {th }}$ century. Political reasoning on the need for cultural modernization and power decentralization included debates on the method of developing education and civic attitudes of people in the new constitutional order. This began to dynamically form after the revolutionary years of $1848 / 1849 .^{2}$ In this discussion fundamental space is also devoted to questions of legal arrangements and the defining of civic and collective national rights (Rusnák, 2013). Among the significant intellectual initiatives in Slovak political thinking of the second half of the $19^{\text {th }}$ century, which reflected, aside from German classical philosophy, Russian thinking and ideas from AngloSaxon empiricism, we can also include the activities of the Catholic priest, writer and journalist Ján Palárik. $^{3}$

In the second half of the $19^{\text {th }}$ century he was established among active Slovak intellectuals who were engaged in discussions on the transformation of the society of that time and debates over the solution to questions of constitutional order of the Austrian monarchy. Since at that time the influence of the estates establishment was subsiding, it was natural that only a minority of citizens of the monarchy possessed political rights. Representatives of the Slovak

\footnotetext{
${ }^{1}$ Slovak Academy of Sciences, Bratislava (Slovakia); martinkovic.marcel@gmail.com

${ }^{2}$ Principle changes in the functioning of state institutions began being implemented only after the end of neoabsolutism (the end of the work of A. Bach in the government). Of importance were imperial constitutional reforms that began being issued by the so-called October Diploma of $20^{\text {th }}$ October, 1860 . These were expanded by the February patent from $26^{\text {th }}$ February, 1861 (Kirschbaum, 2005, pp. 125-144).

${ }^{3}$ In December 2020 we will commemorate 150 years since the death of Ján Palárik, whose thinking had a principle influence on the formation of the so-called New School.
} 
intelligentsia, including Ján Palárik, made up only a small proportion of this group. Despite this quantitative limitation, an intense journalistic debate was a part of the Slovak nation-building process. This was related to the goals and method of political and cultural emancipation of the Slovaks as well as the values that were to be the results of it (Bilasová, 2012, pp. 88-112). With respect to the public engagement of Ján Palárik and his followers, space was created in Slovak political thinking for the development and legitimization of the principles of ideological plurality and public involvement. A part of the public debate among Slovak elites was also the role of reinterpreting the aims of the national movement. Up to that time, a loosely organized group of followers of Ludovít Štúr and Jozef Miloslav Hurban dominated the movement. This group, in terms of its programme and philosophy, continued in the development of the political and cultural principles that had come from the works of Štúr. Their ideological legacy was inspired by the philosophy of J. G. Herder and G. W. F. Hegel, which Štúr first transformed into the romantic-realistic conception of thinking (Pichler, 2001, pp. 111-116).

Its substance in this phase was an effort to maximize the national rights guarateed by law and to use them without regard to the real abilities of the Slovak inhabitants. However, Štur changed this approach in the last phase of his life on the basis of appropriation of the ideas of the Russian Messianism and Slavophilism, ${ }^{4}$ and writer Jonáš Záborský (Krištof, 2013) as well as Ján Palárik stood openly resolved against these aims. ${ }^{5}$ The continuers of Štúr's political legacy at the beginning of the 1860s were integrated into the so-called Martin Wing (the socalled Old School). ${ }^{6}$ Its activities were organized around the periodical Pešt'budínske vedomosti [Pest-Buda news] and denoted national conservatism and Romantic idealism with an emphasis on carrying out aims without regard to the circumstances. Such an interconnection of ethical ideal and politics, theory and practice was characterized within ethics of conviction (Weber, 2004, pp. 83-84). Its essential feature is an effort to realize the idea as an ethically justified aim, regardless of circumstances and possible negative consequences. The legitimacy of this action is based on the emotion and personal persuasion of the moral value to realize this idea through political action. In this case the historical task to guarantee, institutionally, the national development and existence of the Slovak people. The intellectual approach of representatives of the Old School regarding the expansion of political and cultural rights was framed in particular by abstract conceptions of the philosophy of history and the preferred programme unity of the Slovak intelligentsia. That was inspired mainly by the philosophy of history and

\footnotetext{
${ }^{4}$ The philosophical-political discourse that took place in Russia in the first half of the $19^{\text {th }}$ century also had an impact on Slovak thinking through the work of L'udovít Štúr. In this period in Tsarist Russia a debate between socalled "westerners", who sought inspiration in the modernization of Russia in the institutional and cultural environment of Europe (P. J. Chaadayev, Nikolai I. Nadezhdin, T. N. Granovskij etc.), and "Slavophiles" (A. Khomyakov, K. Aksakov, P. V. Kirejevskij, I. etc.) was already taking place. These held positions defending Russian culture, political and religious exclusivity. Among the basic theses of Russian Slavophiles were thoughts idealizing Russian cultural, religious and political specifics. Their thinking reflecting Russia and its cultural traditions founded on the principle of "enlightened tsarism", "velikoderžaija" [big government] and Orthodox spirituality also had an influence on Slovak intellectuals. They became a model in the realizing of national institutionalization of Slovaks, especially in connection with Štúr's work Das Slawenthum und die Welt der Zukunft [Slavism and the World of the Future] (Štúr, 1993; Lopatková, 2019; Haraksim, 2011; Plašienková, Rusnák \& Florio, 2019; Jahelka, 2018).

${ }^{5}$ Palárik entered into the public sphere through the journal Cyril a Metod, which began being published in Banská Štiavnica from $14^{\text {th }}$ March, 1850. In it he devoted himself primarily to the issue of reform of the church environment in the context of the enlightened approach of the priest Bernard Bolzano. His thinking and approach to the need for the transformation of ecclesiastical law, even then, already had a visible overlap into politics.

${ }^{6}$ This was that part of the younger Štúr generation which interpreted and defended in a traditionalist way the text of the Martin Memorandum, which originated at a meeting on $6^{\text {th }}$ and $7^{\text {th }}$ June, 1861 in Turčianský Svätý Martin. The demand made in it for the creation of an administrative unit of Upper Hungary, the Slovak environs, which was populated predominately by Slovak-speaking people, became a point of conflict among Slovak intellectuals. The position regarding this demand ultimately led to differentiation of the Slovak political elite into the mentioned groups, the so-called Old School and the New School (Hollý, 2011).
} 
the thinking of Hegel in the way that it reflected national existence as the highest degree of the realization of The Ghost in history.

The progressive understanding of historical development concerning L'udovít Štúr also became naturally evident in the press proof of the individual Slavic nations. His historical optimism unfolded from the potential of the spiritual increase of the Slavic nations in connection with the idea of the civilization mission of Slavic patriotism. Its source in the Slovak thinking are also the reflections of Johann Gottfried Herder and by him emphasized demonstrations of traditional folk culture and Slavic virtues, which are integrated in the value of humanity. We encounter them initially via Ján Kollár and, also, later in Stúr's thinking. The influence of Herder is shown on the places where the mentioned thinkers extract Slavic virtues, where they make reference to, for example, courage, persistence, humanity. By Štur is their development subsequently connected with the ethical conviction that it is correct to push the national rights of the Slovak people since their development is in accordance with an inevitable historical evolution. An alternative political approach of intellectuals around Ján Palárik, Ján Nepomuk Bobula and their sympathizers subsequently formed around the editorial staff of Slovenské noviny [Slovak News] (1868-1875) and the so-called New School.

Their political programme approached resolution of the issue of national equality from the perspective of a Hungarian patriot, civic liberalism and advocacy of the ideas of political pluralism, freedom of expression and cooperation. In the context of the debate with representatives of the so-called Old School, Palárik emphasizes: "Please, don't immediately preach that every removed opinion is a national betrayal, as if you were national popes and every one of your words dogma. We believe in dogma only in religion, but in politics we want to have freedom of thought and belief' (Palárik, 1956, p. 118). Their central principle was the gradual promotion of political and cultural rights with an emphasis on considering the possibility of real implementation of their goals and minimizing any negative consequences. This strategy of negotiation was framed especially by ethics of responsibility. Its substance was to implement the same aim as by Štúr, an independent development of the Slovak people as a nation in the monarchy. The emphasis was on the responsible choice of the strategy, which also reflected possible negative consequences of the implementation of the given political aim as well as the then state of the cultural and political development of the Slovak people.

This approach did not have the form of abstract reflections about the philosophy of history, but it was aimed at the practical realization of the changes in social practice. Also, for this reason, Palárik, in his journalism, did not directly argue against the works of Hegel. The realization of the national and civil rights, in the thinking of the New School, unfolded, mainly from the practically focused philosophy, an effort to broaden the political maturity and civil competency of the people. Thus, in the given situation the ideas of Romantic idealism where the political action is motivated by feeling, emotionality and abstractly legitimized good intentions and empirical pragmatism, which takes into consideration practical rationality and the importance of political responsibility for the decisions to realize the chosen, ethically justified aims. The central thesis of the New School programme, which drew its ideas from the works of Ján Palárik, became Štúr's reinterpreted idea of the unity of the different. Štúr had articulated this in the linguistic context of a defence of the rights to one's own written language (Štúr, 1953, p. 244) and expanded its original content characterised by Ján Kollár (Kollár, 1837).

The intellectual approaches of both mentioned groups of Slovak intellectuals differed especially in the emphasis on the gradualness of steps for implementing national institutionalization and the formation of civic awareness. Representatives of the Martin Wing attempted to obtain institutional recognition on the basis of power intervention from the political centre. Their effort to realize the national rights of Slovak people proceeded from the idea that a good ethically legitimate aim should be politically asserted in every situation without 
taking into consideration the possible consequences of their political action. The concentration on the realization of the chosen aim without taking into consideration appropriate means that limit it, is considered to be one of the essential aspects of Štúr's thinking, where the ethics of conviction is manifested. The nation-building project of Slovenské noviny [Slovak News] ${ }^{7}$ emphasized the importance of the idea of the unity of the different, the application of which also expanded into the sphere of the political framework of Hungary. In this way they accepted in their thinking Herder's idea of the unity of the different and they broadened its application from the level of culture and language into the civic sphere. ${ }^{8}$

They were aware that the springboard introduction of rights would not have the expected positive effect, if people do not acquire political skills though progressive political education. ${ }^{9}$ They considered the disseminating of civic culture through the acculturation function of associations, newspapers and schools as an essential prerequisite for the success of forming civic culture in a framework of creating ethical responsibility. They thought that education of the people, especially in their mother tongue, together with amendment of laws relating to education and the municipal sphere were the primary tools for expanding the political skills of individuals. The journalistic activities of Ján Palárik and later the New Slovak School represented by J. N. Bobula (Franková, 2018, pp. 58-69) emphasized especially the principle of gradual and systematic expansion of association activities and the civic ethos within Hungary. Palárik defined these in his programme text Nová škola [The New School] (Palárik, 1956, pp. 109-118). The essence of their activities was also the effort to cooperate with moderate Hungarian intellectuals and parties. They saw in a strategy carried out in this way a real possibility of elevating the social and economic status of the common people in parallel. They perceived this as an important attribute for improving political skills, awareness of the importance of ethical standards, and responsibility for public matters within them. In this approach to the social reality we can find some aspects of ethics of responsibility that distinguishes and strictly judges the consequences of the political decisions concerning the realization of the chosen aim.

According to Palárik, the moral knowledge of the people and the will to use it in public policy is expressed only if the people know valid law and resolutely carry it out. In the article Otázka národnosti a nasledovne i literatúry pri novom politickom preporodení Uhorska [The question of nationality and subsequently of literature during the new political rebirth of Hungary] he writes in this context. "Those moral reasons must also be strengthened by legal physical ones, i.e. we must work with resolute will, words and deeds so that we make national rights applicable in life on the path of legality. Otherwise, this will only be negative for us, i.e. the fact that no one denies it in theory; it will be positive, real, valid only when we introduce it in practice, i.e. into life" (Palárik, 1956, p. 41). Without an expansion of the civic ethos, according to Palárik, recognized rights remain only formal and maximizing them may be politically counterproductive. The reason for such a conclusion was the nature of the political discourse of the time, which was radicalized under the influence of Hungarian nationalism.

\footnotetext{
${ }^{7}$ Aside from Bobula and Palárik, we can also place Ján Mallý among those representatives who were active as journalists in Slovak newspapers in various stages of their activities as well as Ladislav Jeszenszký, Móric Philadelphi, Koloman Banšell, Jozef Strakovič, Daniel Bachát, Jakub Graichmann and others.

${ }^{8}$ In this way, Palárik did not follow ideologically Herder's thesis about the civilization mission of the Slavs in the context of reflections about the completion of history through the realization of the principle of humanity. In this aspect was his approach completely different from the reflections of L'. Štúr. Palárik in his articles did not develop the narrative of idealization of the folk forms of culture inspired by Herder. He considered the public commitment with the aim of broadenening and with the action to secure their cultural and political rights, to be a sign of cultural maturity.

${ }^{9}$ Their activities concentrated on increasing the possibilities of education and participation of common people led, among other things, to the founding of the publishing house Minerva and the Národno-demokratického slovenského spolku [National-democratic Slovak Association] in Pest (Kačírek, 2016).
} 


\section{Attributes of ethics of responsibility in the thinking of Ján Palárik}

The deliberations and articles of Ján Palárik focus on the realization of national and civic liberty with an emphasis on ethics of responsibility. Contrary to this, we can also see in Slovak cultural and philosophical discourse a model of ethics of principle. This is based on maximizing the legal guarantee of rights without regard to the political awareness of individuals. The distinction of the outlined ethical concepts for the development of the cultural identity of Slovak intellectuals is philosophical-political in essence. This is evident in the choice of and emphasis on divergent political means while preserving commonly reflected political goals. We can also note the difference in the method of their use and in the legitimization of the selected strategy. Ján Palárik in following the common goal (national institutionalization of the Slovaks) started from the ideas of the emphasized principles of constitutional liberalism, the guaranteeing of language rights when using the mother tongue in the school system and evolutionary development of civic skills. Such a concept of shaping democratic attitudes was inspired by the Anglo-Saxon philosophical tradition of reflecting the relationship of theory and practice.

In it the philosophical concept and theory were not unilaterally superior to practice but were connected with it on the basis of analysing the consequences of its application. An important aspect in Ján Palárik's thinking was thus the moment of removing the unrealistic, romantic aspects of Slovak political thinking and goals, which were a part of the appropriation of abstract philosophical constructs within philosophical history. The result of Palárik's journalism was thus a legitimizing of the idea of practical reasonableness, which emphasizes the importance of a gradual, practically orientated education in which the negative consequences of political perfectionism and the incorrect perception of ideals are absent. The ideas of practical reasonableness in line with ethics of responsibility consider a priori philosophically determined cultural and political goals as problematic. The reason for this statement is that no social limits exist in such a deductive and rationalistic approach to carrying out natural rights. The pragmatism of Ján Palárik stands in opposition to this rationalistic approach to reality. In it we find the basis of modern liberal thinking, which emphasizes the practical importance of philosophy, i.e. realism and the shift away from abstract rationalism. Representatives of philosophical rationalism were able to form a modern projection of the ideal of social equality and freedom.

However, in an effort to maximize them and rapidly implement them (with respect to the historical exceptionality of the political situation in the revolutionary years of 1848/1849 and L. Stúr) they abstracted from objective determinants of the life of the common people of that time. Palárik articulated a different approach to resolving cultural and civic equality in opposition to this idealistic concept of politics. He put emphasis on ethics of responsibility in the scope of a gradual introduction of rights and freedoms into public life. ${ }^{10}$ This involved a concept that respected the principle of so-called empirical democracy. The result of such a connection of ethics and politics is public activity, which is aware of its practical restrictions and limits. A final decision in line with ethics of responsibility is thus always reflected by the cultural, educational, economic and religious specifics of a society and the individual regions within a state (Marchuk, 2016). The positive consequences of legal regulations, according to Palárik, also depend to a significant measure on the practically focused reasonableness of elites and their responsibilities. ${ }^{11}$

\footnotetext{
${ }^{10}$ In this point Palárik started from the period assumptions relating to the development of rights and freedoms, such as L'udovít Štúr in his pre-revolutionary, romantic-realistic thinking.

${ }^{11}$ In reflections on the relation of political theory and practice the followers of Ján Palárik were aware that philosophical rationalism is not a synonym of practical reasonableness. This namely assumes taking empirical limits into account (Sartori, 1987, pp. 51-55).
} 
For this reason, a programme effort for systematic expansion of the possibilities for educating people became a part of Palárik's public engagement. The progress of national selfawareness of the Slovak-speaking population and the forming of a civic ethos were joined with this process. ${ }^{12}$ This important aspect of forming a collective identity in the process of modernization can especially be created through the public activities of individuals. This, however, was limited by several objective socioeconomic, legal and cultural factors. For this reason Palárik emphasized the importance of parallel development of association, cultural and economic activities from below. The reason was the fact that if the state does not observe valid laws in the sphere of education, then educators must provide educational activities, especially on the organizational side.

In connection with resolution of the issue of national inequality of rights, Palárik emphasized in particular the benefit of introducing and developing the principle of the division of power. He sees in constitutionalism the possibility of carrying out the process of decentralization of state institutions in the direction of local self-government. This projected development, in his opinion, will create better opportunities for exercising civil rights in Hungary, which may be positively expressed in the growth of patriotism. He thus perceived the introducing of horizontal divisions of power and at the same time vertical decentralization as an important attribute for ensuring social integrity. The political thinking of Palárik in this situation specifically connected Romantic ideas based on national sentiment, the demands for national equality with Enlightenment ideas emphasizing the practical importance of reason and the right to education with the concept of ethics of responsibility. At the same time he also developed in it the idea of social liberalism, which emphasized the importance of state institutions in this process. Palárik's aim of the evolutionary acculturation of the people in this context also emphasized the support of this process from the Slovak-speaking middle class, lower nobility and landowners.

He also took this approach in situations that some laws coming from the logic of constructionalism were included in the political order of the monarchy only formally and with time limitations. ${ }^{13}$ In the context of raising the level of political awareness of the common people, he also reflected the importance of expanding the space for public discussion on the basis of freedom of expression. "The constitution permits freedom of speech, the freedom to spread one's convictions, the freedom to petition, the freedom of association, and if we Slovaks don't use them wisely on the path to legality, then we will lose them" (Palárik, 1956, p. 30). ${ }^{14}$ He perceived print media in this phase of formation of political literacy on the level of the masses as an essential means of spreading the principles of political pluralism and the formation of civic culture. This was to acquire a more organized and autonomous form with time. The educational-political influence of the press also had, in Palárik's opinion, importance in the context of accelerating the cultural integration of Slovaks, as, at the same time, it substituted for the insufficient functioning of the state education system in the conditions of Hungary. Such a form of socialization should have contributed not only to the expansion of vertical (national) integration but also to the successful engagement of the wider population in the formation of political structures. Promotion of the principles of Enlightenment liberalism, constitutionalism, ideological pluralism (unity of the different), tolerance and legitimization of rights of the

\footnotetext{
${ }^{12}$ For this reason, the development of elementary and secondary school education was among the priorities of the New School. This fact is also documented in the organization of a petition for establishing five purely Slovak and six mixed state grammar schools in 1869.

${ }^{13}$ This category of laws includes the acceptance of the so-called nationalist Act No. 44/1868 and Act No. 38/1868 on Teaching in Primary Schools. These acts did not satisfy all the expectations of Palárik and followers of the New School, but they created, by law, space for the development of the Slovak nation-building process.

${ }^{14}$ Compare with Palárik's article Ćo máme očakávat' od konštitúcie uhorskej pre našu národnost' a čo nám teraz predovšetkým treba? [What Should We Expect from the Constitution of Hungary for Our Nation and What Do We Mainly Need?] (Palárik, 2010, pp. 44-49).
} 
individual in the thinking of Ján Palárik was bound to the reception of the ideas of Charles de Montesquieu.

In aristocratic, monarchist, absolutist and despotic states the people may be simple, unenlightened and uneducated, because what is asked of them there is only a strict obedience and willing fulfilment of higher commands, for which mental blindness and ignorance are certainly better hosted than enlightenment and education - in fact, they would actually be harmful and dangerous for the state. 'Strict obedience', says Montesquieu, 'presupposes ignorance and blindness from the side of those who obey' (Palárik, 1956, p. $64) .{ }^{15}$

In the article Práva l'udu a zákony roku 1848 [The rights of the people and the laws of 1848] he mentions the connection - in context, the interconnection - of the values of freedom and civic responsibility with education: "Because whoever has the right to a goal must also have the right to the means. But without sufficient enlightenment, education and political maturity already, the people cannot enjoy, nor respect, nor further develop, improve, nor hinder the political freedom granted to them in by the laws of 1848" (Palárik, 1956, p. 64). However, Palárik connected the spreading of the Enlightenment as a basic attribute of political liberalism in the $19^{\text {th }}$ century with an emphasis on the mentioned social dimension. The central figure in the context of social liberalism in the Anglo-Saxon environment is John Stuart Mill. In his conception of developmental democracy, he connected the development of the individual rights and freedoms in particular with the development of so-called positive rights. The state should ensure their implementation through mass access to the education system and by guaranteeing freedom of speech, the press and organizations.

Even though Palárik does not explicitly refer to J. S. Mill's thinking, it is evident from the context of his published opinions that he was familiar with his views, as well as with the process of liberalization of rights in England. The reason for this conclusion is the fact that, like Mill, Palárik emphasized the need for the gradual expansion of civic rights depending on the level of education attained. Without the involvement of state institutions in the process of educating the people, the process of liberalization would be difficult to implement. The connection of state activities with the tasks of expanding the education of the people and their participation in politics was, in Palárik, framed by the already mentioned concept of ethics of responsibility. In its essence, we consider a programme of democratic politics founded on an understanding of the importance of shaping the ethical and civic responsibilities of the individual. In this context, political literacy is perceived not only as a means of becoming aware of one's own rights and freedoms, but also a tool for shaping an individual's morals and character.

\section{Political consequences of ethics of responsibility in the thinking of Ján Palárik}

In Ján Palárik we find clearly articulated sympathies for a gradual, evolutionary nation-building strategy. His disagreement with the achieving of political and cultural rights and freedoms in a revolutionary way is also understandable in view of the revolutionary experience of $1848 / 1849 .{ }^{16}$ He sees in the development of the Hungarian constitutional system the best way

\footnotetext{
${ }^{15}$ Palárik accordingly, like Montesquieu, emphasized the coherence between the principles and level of education and values which the given political regime is carrying out. In his most well-known work, The Spirit of Laws, Montesquieu mentions that laws differ depending on the types of government. He considers an establishment where the people participate in the exercise of political power and where the nominal holders of power acquire civic virtues as a democratic regime. In democratic regimes, this is associated with respect for the law, equality, government in the public interest and a sense of civic solidarity and patriotism (Montesquieu, 2001, pp. 37-67).

${ }^{16} \mathrm{We}$ find a similar departure from the positive reflection of the revolution, for example, in the Czech thinking of Karel Havlíček. He notes, among other things, in connection with the preference of the positives of gradual education of the people over revolutionary change. "Revolutions, rebellions, can also free a nation from oppressors - but only for a time, because if the whole nation is not educated, there will soon be wise men who will otherwise
} 
to secure the cultural demands of individual nations. In the context of resolving the dispute over governmental organization between the representatives of centralization or federalization of the Habsburg monarchy, Palárik comes out in favour of the federalist idea. In this context, he again led the debate with representatives of the younger members of Štúr's generation. In the article Na dorozumenie [For Understanding] he writes:

They see the salvation of the Slovak nation in the centralization of Austria. They fought in the 'Vienna Diary' and in brochures as early as 1850 for the centralization of Austria against the federalists, namely against Havlíček; they supported the centralist system of government at least indirectly by fighting for a 'patent'; and now they hope for 'Slovakia environs' from the centralist German government!! - I cannot, not from a Slovak nor from a higher Slavic position, cosy up to such principles. My conviction - I repeat it once again - is: to revive, defend and, by all possible means permitted by the constitution, bring to life the rights of our Slovak nationality, but at the same time to firmly hold with the Hungarian side against the centralist German side while retaining rights, and later, in solidarity with all Hungarian and Austrian Slavs, exacting the others that we still lack (Palárik, 1956, p. $82) .{ }^{17}$

In his view, the federal arrangement of the monarchy should have created more effective solutions to the issue of inequality of nations. Palárik assumed that the principle of subsidiarity could be applied more effectively in such a gradual process of the transformation of society. Palárik's federalism was thus based on the notion of the equality of culturally defined nations.

Thus, justice, and again only justice towards other nationalities living in Hungary, is the only way by which the great work of the new political rebirth of our Hungarian country can be happily accomplished... Now, after a decade of experience of sincere reconciliation and dispassionate, healthy judgement, let us give way. But mutual recognition and justice is this exception. Do not think, you stronger [ones], that you do not need the weaker [ones], or that he cannot harm you, but promise him justice. Fear not the strong, you weak, if you see righteousness and the law prevail in him. May God grant that the peace and prosperity of our Hungarian homeland be modelled on this solid foundation of justice (Palárik, 1956, pp. 39-40).

In this context, the logical consequence of Palárik's political ideas is emphasizing the need for broad political cooperation with regard to the existence of common goals and values. This attitude of his was reflected in the efforts of the New School to develop collaboration in the context of the liberalization of the election, an education and nationality law, as well as with moderate members of the Hungarian political representation. ${ }^{18}$ This central aspect of Palárik's thinking was supplemented with a similar demand regarding the development of political and cultural-literary cooperation of the Slavic nations in the monarchy. Palárik assumed that federalization of the Austro-Hungarian monarchy would lead to the creation of better conditions

be able to impose the old despotism and oppression of the nation on their necks" (Havlíček, 1986, p. 231). (Havlíček, 1986, p. 231). This ideological analogy between Palárik and Karel Havlíček also demonstrates the close perception of political discourse between Czech and Slovak scholars (Havlíček, 2007, pp. 249-254).

17 Similarly, in the article Nová škola [The New School] in an Austro-sceptic approach he recalls that it is impossible to expect "salvation from unreliable supporters and assistants in Vienna, but from the power of the nation itself, according to 'help yourself and God will help you' preferring to look for friends, supporters and loyal allies here at home" (Palárik, 1956, p. 114).

${ }^{18}$ From this perspective, it's necessary to mention the efforts of Ján N. Bobula in the late 1860s. In this period, he tried to establish cooperation with representatives of the Hungarian far left (for example, with Virgil Szilágyi) organized around the magazine Magyar Ujság. At the same time, they also developed cooperation with Adolf Szentiványi and Pavol Madocsányi as members of the Hungarian Diet. 
for cultural self-government in individual parts of the state. ${ }^{19} \mathrm{He}$ also connected the benefit of federalization with the possibility of applying the idea of Slavic reciprocity as a suitable broker of the emancipatory efforts of Slavic nations in the monarchy. We can also mention the article O vzájomnosti slovanskej [On Slavic Reciprocity] among those that articulate the close connection of the above-mentioned ideas (Palárik, 1956, pp. 173-192). In it he distances himself from the perception of the idea of Slavic reciprocity, the aim of which should be the political and cultural unification of the Slavs.

He regards free cooperation and practical cultural and political assistance in promoting the principles of national equality within existing states to be its essence. In this aspect, Palárik did not follow Hegel's philosophical reflections where he reflects the national state as the highest level of the social organisation that has a priori legitimacy. Palárik reflected the meaning of a state in close connection to the realization of the basic functions of the development of society where he also included also the development of the national and civic rights. For this reason he did not identify with Hegel's idea that the highlight of the historical development of society is an institutional covering of the nation by the state. Palárik did not ideologically establish Štúr's interpretation of Hegel's philosophy of history from which he unfolded his idea of an approaching highlight of a civilization dispute between The West and The East. In this dispute should have been the unity of Slavic patriotism under the cultural and political hegemony of the Russian nation as an exclusive bearer of the essentiality of Slavic patriotism. Palárik pointed out the risks of spreading the idea of Slavic reciprocity in the form of political pan-Slavism. He publicly distanced himself from such an unrealistic notion on the content of Slavic cooperation, the result of which was to be the cultural and political unification of Slavic nations.

In this context, his pragmatic and critical view of the role of Russia, or Russian political elites, at that time on the issue of resolving national equality in the Habsburg monarchy is understandable. Palárik respected the contribution of Russian culture and literature in relation to Slovak culture. However, in the field of the political struggle for civil and collective rights, he did not seek real support (in contrast to the Messianistic vision of Štúr and the later idealism of Hurban-Vajanský) among representatives of Russian political elites (Martinkovič, 2011). He considered the attachment of some Slavic scholars to Russia as a state actor that will intervene in resolving the issue of the inequality of nations in the Habsburg monarchy as a counterproductive mystification and a consequence of applying ethics of conviction. In the above-mentioned article $O$ vzájomnosti slovanskej [On Slavic reciprocity] Palárik states in this context:

[D]ue to the misunderstanding of Slavic reciprocity by some Slavs, a misconception about political pan-Slavism has spread throughout all of Europe in this sense: as if the efforts of Slavs were really directed towards Russian centralization. How much such misleading perceptions of Slavic reciprocity have harmed the Slavs can in no way be described. (...) And this misunderstanding, which has damaged us so much, was caused by some overzealous apostles of Slavic reciprocity through the use of fiery, often impetuous, or insufficiently certain expressions of sympathy for the Russians, as they understood those sympathies in the political sense" (...) We embrace the Russian nation with all-Slavic love and wish it well in its national development and noble efforts for civil and political freedom, and in the spirit of genuine Slavic reciprocity we want to support it (Palárik, 1956, pp. 191192). ${ }^{20}$

\footnotetext{
${ }^{19}$ Palárik's principle text advocating federalization of the monarchy in connection with emphasis on the free cooperation of Slavs is a set of articles in Slovenské noviny [Slovak News] titled Účel Austrie pod centralizmom a dualizmom [The purpose of Austria under centralism and dualism] (Palárik, 1956, pp. 84-108).

${ }^{20}$ Thus, even in this context, the last stage of Štúr's political thinking, who uncritically appeals to the political, religious and cultural significance of Russia in the implementation of the national institutionalization of the Slavic nations, seems to be a complete denial of its previous nation-building.
} 
According to Palárik, such a form of Slavic cooperation, which sees its essence in mutual culturally enrichment, leads to the securing of national rights. This is founded on political cooperation while respecting state borders, national specifics and the value of civic rights and freedoms. Palárik was aware of the differences and cultural and religious specifics between the individual Slavic nations and the state of development of individual states. For this reason, he reflects on Slavic reciprocity not as an abstract idea but as a platform for voluntary cooperation in ensuring freedom and national equality. Palárik openly distances himself from the content of pan-Slavic reciprocity, whose ideal is to create a unified empire of Slavs under Tsarist Russia. ${ }^{21}$ In addition, he rejects the delimitation of Ján Kollár's Slavic reciprocity to only the sphere of culture and literature (Palárik, 1956, pp. 183-184). Palárik connects the foundation of Slavic reciprocity in relation to the idea of the unity of the different with the development of mutual organizational and financial cooperation without separatist, disintegrating consequences for existing states. Here again, a concept of ethics of responsibility that respects the framework of constitutional principles, practical reasonableness and pluralism is evident in Palárik.

\section{Conclusion}

The development of the individual attributes of ethics of responsibility in connection with the principles of civic liberalism in Slovak political thought of the second half of the $19^{\text {th }}$ century is tied to the thinking of Ján Palárik. His political considerations arise from an effort to characterize and achieve functional reform of the state organization of the monarchy on the basis of constitutionalism and federalization. In Palárik's view, these attributes should bring more effective solutions to the issue of educating the people in their mother tongue. $\mathrm{He}$ considered the exercise of this right as a starting point for the creation of a civic political culture. A component of Palárik's articles is the defence of freedom of speech, the idea of pluralism, a gradual strategy for realizing national and civil freedom, i.e. the asserting of political rights from below. In this context, he implemented Štúr's idea of the unity of the different into the Hungarian political framework. He also applied an expanded idea of the unity of the different to Slavic reciprocity.

He found its essence and meaning in free and voluntary cooperation in the fulfilment of national and civil rights of the Slavic nations in the Habsburg monarchy. His realistic approach in the perception of the role of Russia in the national emancipation process of the Slovaks was framed by knowledge of the political limits of the Tsarist establishment. In Palárik's politicalphilosophical thinking we find an appropriation of the Enlightenment philosophical tradition and its reflection of the relationship between the individual and society, in which emphasis was placed on the value of the individual and the principle of equality in the exercise of freedom. The intensity of an individual's participation in the political framework and his social status in this concept are related especially to the level of education achieved. This is a prerequisite for the acquisition of civic skills. At the same time, we also find elements of German idealistic philosophy in the political thinking of Palárik, which stressed the importance of the whole, which in his thinking we can find in the emphasis on the interconnectedness of the development of individual (civic) and collective (national) rights within the borders of monarchy.

He linked the development of the state with the application of the principles of practical reasonableness and ethics of responsibility. He found its essence in the understanding the

\footnotetext{
21 "Slavic reciprocity leaves foreign nations and governments at peace; it does not disturb the right of others, (...) it only wants the right of Slavic nations to also be protected by other, namely ruling governments, and the national development and prosperity of Slavs to be ensured in the states in which they live" (Palárik, 1956, p. 184). This stance regarding the content of the idea of Pan-Slavism, which was to lead to the integration of Slavic nations into one state under Russian domination, was subsequently rejected by other representatives of the New School. Their attitude emerged from reflections on the views of part of the Russian elite. This fact is evidenced, for example, by an article by Koloman Banšell My a panslavizmus [We and Pan-Slavism] (Banšell, 1873).
} 
interconnectedness of political aims and ideals, which were to be reflected in close association with the real limitations of the abilities of individuals and social circumstances. Thus, the struggle for the implementation of the principles of national and civic equality is, in Ján Palárik's view, closely connected with the level of acculturation of the individual and with the development of his legal, civic and ethical awareness of responsibility for himself and his surroundings. In addition, on the basis of Palárik's writings, the importance of civic culture in the nation-building process began to be reflected in the environment of Slovak-speaking elites, the basic content of which includes awareness of the value of the freedom of speech and the press, the principle of pluralism and civic solidarity with other members of society. For this reason, Palárik emphasizes the importance of forming public institutions which are helpful in the creation of an environment in which an individual develops responsibility for his own freedom.

This individualizing emphasis (Gellner, 1998, pp. 14-39) creates in parallel the potential for the development of democratic processes and simultaneously cultural specifics as the basis for the development of Hungarian patriotism based on the principles of ethics of responsibility and equality. Even though Palárik's programme of development of a civic ethos did not find wider political support at that time, it was a major contribution in the public discourse of Slovak scholars. His ideas of a necessary connection between the development of national individuality and civil freedom on the basis of the principle of ethics of responsibility led to the disruption of the intellectual monopoly of the historical-romantic concept of Ludovít Štúr and his successors. Palárik's thinking thus contributed to the establishment of a new progressive current in Slovak political-philosophical thinking.

\section{Acknowledgement}

This article was supported by the project "Procesy recepcie a apropriácie ideí v dejinách filozofického a politického myslenia na Slovensku" [Processes of reception and appropriation of ideas in the history of philosophical and political thought in Slovakia: conceptualization of key issues], VEGA project no. 2/0116/19.

\section{References}

BANŠELL, K. (1873): My a panslavizmus [We and pan-Slavism]. In: Slovenské noviny, 6(89), pp. 1-2.

BILASOVÁ, V. (2012): Étos, dejiny, súčasnost' [Ethos, history and the present]. Prešov: FF PU.

ERSOY, A., GÓRNY, M. \& KECHRIOTIS, V. (ed.) (2010): Modernism. Budapest: Central European University Press.

FRANKOVÁ, L. (2018): Ján Nepomuk Bobula (k občiansko-národným postojom na pôde Novej školy) [Ján Nepomuk Bobula (On civic-national attitudes in the New School)]. In: Dejiny, 12(1), pp. 58-69. [online] [Retrieved April 25, 2020] Available at: http://dejiny.unipo.sk/PDF/2018/04_1_2018.pdf.

GAŠPARÍK, M. (1952): Ján Palárik̄ ajeho boj o demokratizáciu slovenského národného života [Ján Palárik and his struggle for democratization of Slovak national life]. Bratislava: Nakladatel'stvo Slovenskej akadémie vied a umení.

GELLNER, E. (1998): Language and solitude. Cambridge: Cambridge University Press.

GLUCHMAN, V. (2012): Podoby humanitného ideálu v slovenskom etickom myslení 19. storočia a prvej polovice 20. storočia [Forms of the humanitarian ideal in Slovak ethical thinking of the 19th century and the first half of the 20th century]. In: V. Gluchman (ed.): Etika na Slovensku (19. a 20. storočie) [Ethics in Slovakia (19th and 20th centuries)]. Prešov: FF PU, pp. 11-60. 
HARAKSIM, L. (2011): Slovak Slavism and Panslavism. In: M. Teich, D. Kováč \& M. Brown (eds.): Slovakia in history. Cambridge: Cambridge University Press, pp. 101-119.

HAVLÍČEK, K. (2007): The Slav and the Czech. In: B. Trencséniy \& M. Kopeček (eds.): National Romanticism: The formation of national movements. Budapest: Central European University Press, pp. 249-254.

HAVLÍČEK, K. (1986): Dílo II. Pražské noviny, Národní noviny, Slovan [Work II: The Prague News, The National news, The Slovan]. Praha: Československý spisovatel.

HAYDANKA, Y. (2014): Democratic transit model in its theoretical and empirical dimensions. In: The Journal of V. N. Karazin Kharkiv National University. Series Issues of Political Science, 1111, pp. 72-77.

HOLLÝ, K. (2011): Memorandum národa slovenského ako historiografický prameň [The Memorandum of the Slovak nation as an historical source]. In: J. Pekarovičová, M. Vojtech \& E. Španová (eds.): Studia Academica Slovaca 40. Bratislava: Univerzita Komenského, pp. 101114.

JAHELKA, T. (2018): Ideové spory v slovenskom politickom myslení pred a po roku 1918 [Ideological controversies in Slovak political thought before and after 1918]. In: Filosofický časopis, 66(5), pp. 771-788.

KAČIIREK, L. (2016): Národný źivot Slovákov v Pešt'budíne v rokoch 1850-1875 [The national life of the Slovaks in Budapest, 1850-1875]. Békescsaba: Výskumný ústav Slovákov v Mad'arsku.

KATUNINEC, M. (2007): Civic responsibility in a democracy of values. Trnava: Königswinter \& Trnava University.

KIRSCHBAUM, S. J. (2005): A history of Slovakia. New York: Palgrave MacMillan.

KOLLÁR, J. (1837): Über die literarische Wechselseitigkeit zwischen den verschiedenen Stammen und Mundarten der slawischen Nation [About the literary reciprocity between the different tribes and dialects of the Slavic nation]. Pesth: Trattner \& Károlyi.

KRIŠTOF, P. (2013): Záborského neromantická koncepcia nacionalizmu [Záborský’s nonromantic conception of nationalism]. In: Forum Historiae, 13(2), pp. 21-33.

LOPATKOVÁ, Z. (2019): Niekol'ko poznámok k Štúrovej spolupráci s predstavitel'mi slovanských národov v polovici 19. storočia [Some notes on Štúr's cooperation with representatives of the Slavic nations in the middle of the 19th century]. In: M. Kohútová \& M. Marek (eds.): Studia Historica Tyrnaviensia XX. Trnava: Towarzystwo Słowaków w Polsce a FF TU, pp. 247-266.

MARCHUK, V. (2016): Church, spirituality, nation. Ivano-Frankivsk: Play.

MARTINKOVIČ, M. (2011): Historicistická koncepcia slovanstva v politickom myslení S. H. Vajanského [Historicist Conception of Slavism in Political Thinking of S. H. Vajanský]. In: Filozofia, 66(10), pp. 1013-1023.

MAXWELL, A. (2009): Choosing Slovakia: Slavic Hungary, the Czechoslovak language and accidental nationalism. London \& New York: I. B. Tauris Publishers.

MONTESQUIEU, CH. (2001): The spirit of laws. Kitchener: Batoche Books Kitchener.

PALÁRIK, J. (2010): What Should We Expect from the Constitution of Hungary for Our Nation and What Do We Mainly Need? In: A. Ersoy, M. Górny \& V. Kechriotis (eds.): Modernism. Budapest: CEU Press, pp. 44-49.

PALÁRIK, J. (1956): Za reč a práva l'udu (II. zväzok diela) [For the language and the rights of the People, vol. II]. Bratislava: Slovenské vydavatel'stvo krásnej literatúry.

PICHLER, T. (2011): Etnos a polis [Ethnos and polis]. Bratislava: Kalligram.

PICHLER, T. (2001): Probleme, Möglichkeiten und Grenzen eines slowakischen Liberalismus dargestellt am Beispiel Ján Paláriks. In: D. Kováč, A. Suppan \& E. Hrabovec (eds.): Die Habsburgermonarchie und die Slowaken 1849-1867. Bratislava: Academic Electronic Press, pp. 111-116. 
PLAŠIENKOVÁ, Z., RUSNÁK, P. \& FLORIO, L. (2019): Alexei Khomiakov, Pierre Teilhard de Chardin, and Ladislav Hanus: Three points of view on faith and Church in human life. In: V. Mrówczyński, T. Obolevich \& P. Rojek (eds.): Alexei Khomiakov: The mystery of Sobornost'. Oregon: Pickwick/Wipf and Stock Publishers, pp. 203-216.

RUSNÁK, P. (2013): Selected impacts of the dispute between liberalism and communitarianism in contemporary ethics and law. In: Ethics \& Bioethics (in Central Europe), 3(1-2), pp. 87-96.

SARTORI, G. (1987): The theory of democracy revisited. Part one: The contemporary debate. London: Chatham House Publishers.

ŠTÚR, L. (1953): Reči a state [Speeches and articles]. Bratislava: Slovenské vydavatel'stvo krásnej literatúry.

ŠTÚR, L. (1931): Das Slawenthum und die Welt der Zukunft [Slavdom and the World of the Future]. Praha: Učená společnost Šafaříkova v Bratislavě.

VAVROVIČ, J. (1974): Jean Palárik. Cleveland \& Rome: Slovak Institute.

VÁROSSOVÁ, E. (1963): Slovenské obrodenecké myslenie [Slovak revivalist thinking]. Bratislava: Slovenská akadémia vied.

WEBER, M. (2004): The vocation lectures. Indianapolis \& Cambridge: Hackett Publishing Company. 